Division of Geological \& Geophysical Surveys

MISCELLANEOUS PUBLICATION 147P

\title{
ANNOTATED BIBLIOGRAPHY SERIES IN SUPPORT OF COASTAL COMMUNITY HAZARD PLANNING-NORTHWEST ALASKA SCAMMON BAY, ALASKA
}

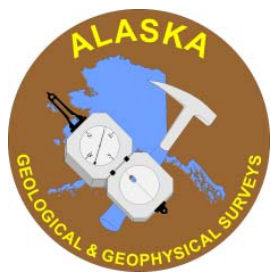

Prepared by Jacquelyn Smith and Nicole Kinsman November 2011

Scammon Bay

This annotated bibliography is part of a series created to facilitate access to documents useful for coastal geohazard evaluation and community planning in Northwest Alaska. Below is a comprehensive list of community-specific information sources, each with full bibliographic information and an informative-style annotation that highlights content pertaining to the community of Scammon Bay, Alaska. For a detailed description of the preparation and scope of this resource, please refer to this bibliography series' foreword. Any notable errors and/or omissions may be reported to the Coastal Hazards Program manager at the Alaska Division of Geological \& Geophysical Surveys (DGGS).

Alaska Department of Commerce, Community \& Economic Development (DCCED), accessed 2011, Division of Community \& Regional Affairs (DCRA) Community Profiles [website]: State of Alaska Department of Commerce, Community \& Economic Development.

http://www.commerce.state.ak.us/dca/profiles/profile-maps.htm

This website provides access to community profile maps for community-based planning. The maps are available in 24" by 36" and 30" by 42" formats. The Scammon Bay maps were created in 2007, 1994, and 1979 based on land surveys and/or interpretation of aerial imagery. Subsistence hunting grounds, habitat areas, community buildings, and public facilities are delineated. Shoreline position and potential erosion zones are included in the map content. All maps have been sponsored by the Alaska Division of Community \& Regional Affairs and contracted to local agencies for production.

Alaska Department of Natural Resources Division of Coastal and Ocean Management (DCOM), accessed February 2011, Alaska Coastal Management Program [website]: Alaska Department of Natural Resources Division of Coastal and Ocean Management.

http://alaskacoast.state.ak.us/Explore/Tour.html

This website outlines the Alaska Coastal Management Plans for each coastal district. It provides stewardship plans "to ensure a healthy and vibrant Alaskan coast that efficiently sustains long-term economic and environmental productivity."

Alix, Claire, 2005, Deciphering the impact of change on the driftwood cycle-Contribution to the study of human use of wood in the Arctic: Global and Planetary Change, vol. 47, p. 83-98.

In this article, the author describes the quantity, quality, and geographic distribution of driftwood associated with specific climatic and ecological conditions in arctic Alaska. The conditions favorable to driftwood production are linked to the abundance of building materials available for use by indigenous populations. The environmental factors involved in driftwood travel include flooding, storm patterns, ocean surface currents, wind, and ice, all of which may undergo changes linked to global climate patterns. The author discusses regional variables affecting driftwood travel as well as the availability of this material on beaches throughout the entire arctic. Radiocarbon dating of driftwood and recorded interviews with elders were used to document driftwood distribution and composition within the study area. 
Blier, Warren, Stanley Keefe, Wilson A. Shaffer, and Sung C. Kim, December 1997, Storm surges in the region of western Alaska: Monthly Weather Review, vol. 125 p. 3094-3108.

The authors describe the relationship between storm surges in Alaska and extratropical cyclones. They have identified Norton Sound and the Bering Sea as the two regions most vulnerable to cyclone-linked coastal flooding. A statistical storm surge model was developed to provide advance warning to coastal villages; however, the author highlights that a more accurate model would be necessary to utilize this warning system as a hazard mitigation strategy. The installation of storm-surge gauges would also be required for this warning system to be used successfully.

Cacchione, David A., and David E. Drake, 1979, Sediment transport in Norton Sound, Alaska: U.S. Geological Survey, Open File Report 79-1555, 88 p.

This report is an investigation of sediment dynamics in Norton Sound and the northern Bering Sea. The major topic of the research was sediment movement and hydrodynamic stresses that occur in the Sound and their relationship to Bering Sea ocean dynamics. Other studies have found sediment accumulation from the Yukon River inconsistent with the rate of supply. The modes of transport for this loss of materials are discussed in the report. This study attempts to provide a description of the bottom transport of sediments, pollutants, nutrients, and other particulate matter, as well as identify hazardous sea floor conditions in Norton Sound.

Chikita, Kazuhisa A., Richard Kemnitz, and Ryuji Kumai, 2002, Characteristics of sediment discharge in the subarctic Yukon River, Alaska: Catena, vol. 48, p. 235-253.

The authors describe the construction of a physical model of sediment discharge from the Yukon River. The study uses the results of observations made in 1999 to characterize temporal patterns in the volume of sediment discharged by the Yukon River. The results of this study reveal that peak sediment discharge did not coincide with peak water discharge. The peak sediment discharge was linked to glacier-melt from summer to autumn, while peak water discharge was linked to snowmelt in the spring.

Denali Commission, March 2011, Road and waterfront project selections, fiscal year 2006-2011: Denali Commission, 9 p.

This report contains a description of all of the funding dispersed by the Denali Commission Transportation Program from 2006-2011. The document is organized by project and includes completion status. Scammon Bay was appropriated \$1,689,134 for the rehabilitation of community streets in 2010; the project is currently in the design and construction stage.

DeSimone, H.F., November 1971, Final environmental Impact Statement airport project at Scammon Bay, Alaska: Alaska Division of Aviation, no. PB-202 306-F, 14 p.

This statement addresses the environmental impact of the proposed construction of a new landing strip, a new parking apron, a connecting taxiway, and incidental items including rudimentary access roads, wind cone, and segmented circle for the Scammon Bay airport. The environmental impact is expected to be low, with considerations of additional ambient noise being the biggest concern. Any possible pollution is low relative to the community heating systems.

Drake, D.E., D.A. Cacchione, R.D. Muench, and C.H. Nelson, 1980, Sediment transport in Norton Sound, Alaska: Marine Geology, vol. 36, p. 97-126.

This study examines the suspended sediment and ocean circulation of the northeastern part of the Bering Sea shelf. The authors describe the fate of sediment delivered by the Yukon River to the southwestern corner of Norton Sound and the importance of storm events in Norton Sound associated with erosion and sediment transport. Landsat images were also used to inspect the distribution of sediments and regional circulation in the Sound.

Hathaway, Russel, ed., May 1991, Environmental assessment, Scammon Bay airport improvements: Alaska Department of Transportation \& Public Facilities and Federal Aviation Administration, project no. 57981, 41 p.

This report discusses the environmental impact of lengthening the runway safety area and constructing two sections of haul road at the Scammon Bay airport. Because Scammon Bay is located mountainside, it is rated low for flood hazard according to the Corps of Engineers. No significant impacts are of concern for the construction project. Included in the report are maps of the project site and gravel borrow area. 
Immediate Action Workgroup (IAWG), Michael Black and Patricia Opheen, eds., March 2009, Recommendations to the Governor's Subcabinet on Climate Change: Immediate Action Workgroup, 162 p.

The Immediate Action Workgroup was established to address known threats to Alaskan communities caused by coastal erosion, thawing permafrost, flooding, and fires. This report is a follow-up to the recommendations made in April 2008 (in which Scammon Bay was not mentioned), and provides recommendations of actions and policies to be implemented in 2009 and 2010. Scammon Bay has a reported flood in 1979, and is identified as receiving agency actions from the Division of Emergency Management.

Jorgenson, Torre and Craig Ely, 2001, Topography and flooding of coastal ecosystems on the Yukon-Kuskokwim Delta, Alaska-Implications for sea-level rise: Journal of Coastal Research, vol. 17, no. 1, p. 124-136.

This study includes the comparison of vegetation, sedimentation, and annual peak flooding conditions at varying elevations in coastal ecosystems on the Yukon-Kuskokwim Delta. These relationships were then used to evaluate which coastal ecosystems are most susceptible to tidal inundation from sea-level rise. The study was located along the Kashunuk River and Angyoyaravak Bay, directly southeast Scammon Bay.

Lower Kuskokwim Economic Development Council, June 2006, Lower Kuskokwim Economic Development Council comprehensive economic development strategy and area plan: Lower Kuskokwim Economic Development Council, Bethel, Alaska, 28 p.

This report presents an economic development strategy by the Lower Kuskokwim Economic Development Council (LKEDC). The purpose of this report is to identify a more stable and diversified economy, assist in creating employment opportunities, improve local economic conditions, and act as a catalyst for guiding and coordinating the efforts of individuals and organizations concerned with sustainable economic and natural resource development in the region. The main areas of economic development are the promotion of fisheries resources, tourism, and infrastructure development, job development, and the coordination of LKEDC services to local residents. Specific communication efforts, opportunities, and goals are listed for each subject, including watershed management.

Maynard and Partch, 1984, Capital improvements program briefing paper Yukon-Kuskokwim needs assessment and regional plan: Alaska Department of Community \& Regional Affairs (DCRA), 79 p.

This report identifies the multi-year capital improvement needs for 50 communities in the Yukon-Kuskokwim Region. The region was chosen for study because of the rapid change from subsistence to cash based economy. The capital improvements are summarized in tables for each community and are at a scale that will bring substantial benefits to the region.

Tetra Tech for Immediate Action Workgroup: Advisory Group of the Governor's Climate Change Sub-Cabinet, June 2010, Imperiled community water resources analysis: Anchorage, Alaska, Tetra Tech, 47 p.

This report summarizes climate-related threats to water and wastewater infrastructure in Alaskan communities including those at risk to flooding, saltwater intrusion, loss of surface water supply, erosion, and sedimentation of the source region. The primary objectives of the analysis were to:

1. Identify and select study group communities whose water infrastructure is threatened

2. Collect information on the threatened water infrastructure for the study group communities

3. Analyze information to determine the climate-related impacts to study group community water infrastructure (p. 2)

Scammon Bay has not had erosion problems reported caused by the Kun River; however, erosion is occurring at sites built on substandard fill. The mode of erosion identified in this report is permafrost melting.

Thorsteinson, Lyman K., Paul R. Becker, and David A. Hale, 1989, The Yukon Delta-A synthesis of information: National Oceanic and Atmospheric Administration (NOAA), Anchorage, Alaska, OCS study no. MMS 890081, $89 \mathrm{p}$.

This document contains a synthesis of physical and ecological information about the Yukon-Kuskokwim River Delta. "[Since 1974], the Outer Continental Shelf Environmental Assessment Program has administered oceanographic research to characterize the environmental components and processes of the Alaskan Outer Continental Shelf." This research, once primarily based on oil and gas exploration, has provoked interest about the importance of the physical and biological habitats of the delta. 
The physical environment is described in terms of geomorphology, hydrology, bathymetry, sedimentology, coastal circulation, hydrography, and environmental sensitivity mapping. The biological environment is described in terms of primary productivity, invertebrates, fisheries, avifauna, and mammals.

Areas of research highlighted as in need of further exploration are ice-edge effects, prevailing sea ice movements to the southwest, and subsurface northwesterly transport of Norton Sound water masses. If oil and gas exploration develops, more work must be conducted to determine the effects that this activity would have on the estuarine habitat.

U.S. Army Corps of Engineers, accessed 2011, Civil works floodplain management services [website]: U.S. Army Corps of Engineers, Alaska District.

http://www.poa.usace.army.mil/en/cw/fld_haz/floodplain_index.htm

This website provides flood-hazard data for communities throughout Alaska. A link is provided to a floodhazard-specific bibliography, maintained by the U.S. Army Corps of Engineers. Standard flood data is not available for Scammon Bay, but comments regarding flooding events are available.

U.S. Army Corps of Engineers, March 1982, Scammon Bay, Alaska small hydropower interim feasibility study and environmental assessment: U.S. Army Corps of Engineers, Alaska District, 62 p.

Due to the increase in electrical generation cost to Scammon Bay, this study considers the economic and environmental feasibility of various alternatives to either supplement or replace diesel generation. The hydroelectric project would consist of a rock-filled gabion dam. Estimated energy output based on stream-flow data is available with projections to 1995. Project site geology and material sources are discussed, but not conclusive; more testing is required.

U.S. Government Accounting Office (GAO), 2003 [2004], Alaska Native villages—Most are affected by flooding and erosion, but few qualify for federal assistance: U.S. General Accounting Office Report GAO-04-142, 82 p.

http://www.gao.gov/products/GAO-04-142

This study was conducted to provide recommendations to Congress that would improve how state and federal agencies respond to flooding and erosion in Alaska. This was done by:

1. Determining the extent to which these villages were affected.

2. Identifying federal and state flooding and erosion programs.

3. Determining the current status of efforts to respond to flooding and erosion in nine villages.

4. Identifying alternatives that Congress may wish to consider when providing assistance for flooding and erosion (from "Highlights" section).

The recommendations provide alternatives to current actions taken during flooding and erosion responses by including federal agencies and the Denali Commission. The adoption of policies by the Denali Commission would guide investments in infrastructure for Alaska Native villages affected by flooding and erosion. Scammon Bay is identified as one of 184 Alaska Native villages affected by flooding and erosion.

Walters, L., and M. Cushing, 1995, Community profile-Scammon Bay: Alaska Department of Community \& Regional Affairs (DCRA), 19 p.

This profile includes information on the community's status in the following areas: Facilities, U.S. Census, economy and employment, schools, rural businesses, contacts, municipal officials, municipal finances, rural grants, and ANCSA land status.

Wise, James L., Albert L. Comiskey, and Richard Becker, 1981, Storm surge climatology and forecasting in Alaska: Anchorage, Alaska, Arctic Environmental Information and Data Center, University of Alaska, 26 p.

The objective of this study was to improve the quality of life and the security of property in coastal areas susceptible to flooding by enhancing the decision-making process for human activities and development. This study compiles historical climate data to develop a surge forecast regression equation.

The offshore shape of the sea floor in the lower Kuskokwim and Bristol Bay area is identified as conducive to the formation and enhancement of storm surges. Storm profiles specific to Scammon Bay are recorded for 1974 and 1979. 